\title{
PENGARUH INFLASI, KURS, DAN BI 7-DAY RATE TERHADAP INDEKS SAHAM SYARIAH INDONESIA (ISSI) PERIODE 2015-2020
}

\author{
Susilo Adi Saputra ${ }^{1}$, Chenny Maulyca Gloria ${ }^{2}$, Asnaini ${ }^{3}$ \\ 1,23,Institut Agama Islam Negeri Bengkulu \\ $\triangle 1$ susilosaputra72@gmail.com, $\triangle^{2}$ chennymaulycag26@gmail.com, \\ 凹3asnainibkl@yahoo.co.id
}

\begin{abstract}
The purpose of this study is to analyze the effect of inflation, exchange rates, and bi-7-day ratios on the Indonesian Sharia Stock Index (ISSI) for the 2015-2020 period. The method used in this research is to collect data such as through website and library studies. Data analysis in this study uses multiple ECM analysis with the help of the Eviews 8 computer program. The results of this analysis indicate that the inflation variable has an influence on the Indonesian Islamic stock index. However, the exchange rate and the bi 7 day rate do not have a significant effect on the Indonesian Islamic stock index.
\end{abstract}

Keywords : Indonesia sharia stock index, BI 7-day rate, exchange rate, inflation.

\section{LATAR BELAKANG}

Pesar modal syariah di Indonesia telah berkembang selama dua dekade, yaitu sejak dilancarkan pada reksadana syariah pada tahun 1997. Pasar modal syariah memberikan bagi kalangan muslim maupun non muslim yang ingin melakukan investasi dana yang sesuai dengan prinsip syariah. Pada saat ini pasar modal syariah meningkatkan peran jumlah investor di pasar modal selama pasar modal syariah lebih popular, sebagai sebuah wacana dimana banyak bicara tentang bagaimana pasar di syariahkan (Nurafiati, 2019)(Hana, 2018). Perkembangan saham syariah cukup signifikan membuat para investor mulai menarik saham-saham berbasis syariah dilihat dari kinerja pasar modal syariah pergerakan Indeks Saham Syariah Indonesia (ISSI) mengalami perkembangan signifikan tentu hal tersebut di pengaruhi berbagai faktor (Aisiyah \& Khoiroh, 2015)(Ulinnuha, Susilowati, \& Hana, 2020).

Menurut Irham (2015), pada Inflasi ini merupakan suatu kejadian yang menggambarkan situasi dan kondisi di mana harga barang mengalami kenaikan dan mata uang mengalami pelemahan (Produk et al., 2016). (Aisiyah \& Khoiroh, 2015) mengatakan bahwa Inflasi, Nilai Tukar IDR/USR, Sertifikat Bank Indonesia Syariah (SBIS) dan harga minyak dunia bisa mempengaruhi ISSI secara signifikan. Menurut Yulianto (2015) kondisi makro ekonomi suatu negara juga dapat mempengaruhi oleh harga saham, Theresia dan Arilyn (2015) menyatakan bahwa harga saham menjadi dasar pertimbangan investasi bagi para investor karena harga saham mencerminkan nilai perusahaan. Menurut Dewi dan Suryana (2016) saham yang telah dibeli mengalami kenaikan sedangkan pihak penjual saham mengharapkan harga saham yang telah dijual mengalami penurunan, hal ini akan mengakibatkan harga saham berfluktuatif (Selpiana \& Badjra, 2018). Menurut Priana dan Muliartha (2017) Semakin tinggi volatilitas harga saham, maka semakin besar kemungkinan harga saham naik dan turun secara cepat (Inflasi et al., 2019)

Nuraini (2018) menyatakan bahwa kurs rupiah mempunyai pengaruh secara negatif dan signifikan terhadap IHSG, karena dianggap lebih menguntungkan dengan 
resiko yang lebih kecil (S \& Ekonomi, 1945). Ardelia dan Saparila (2018) menyatakan pada tahun 2019 yang membaik mendukung nilai tukar rupiah yang menguat dengan volatilitas yang menurun (Indeks, Syariah, \& Issi, 2020). Menurut Dewi dan Suaryana (2016) Volatilitas harga saham menjadi perhatian bagi para pelaku pasar di pasar modal karena dijadikan sebagai acuan untuk menentukan strategi yang tepat dalam berinvestasi (Selpiana \& Badjra, 2018). Menurut Jannah dan Haridhi (2016) informasi mengenai kebijakan dividen berkaitan dengan teori sinyal, karena informasi tersebut memberikan sinyal kepada investor mengenai kinerja perusahaan dalam jangka panjang dan menarik minat investor untuk menanamkan dananya pada saham tersebut. Sehingga permintaan akan saham naik dan pada akhirnya menyebabkan nilai saham juga akan naik (Selpiana \& Badjra, 2018). Pada hasil penelitian yang dilakukan oleh Dianita Listya Nuraini (2018) menyatakan bahwa BI Rate dapat berpengaruh secara positif dan signifikan terhadap IHSG (S \& Ekonomi, 1945). Hal ini dapat berbanding terbalik dengan hasil penilitian yang dilakukan Ardelia dan Saparila (2018) yang menunjukan bahwa BI Rate mempunyai pengaruh yang negatif dan signifikan terhadap IHSG (Sbi, Indeks, Saham, \& Ihsg, 2018).

Penelitian ini merupakan perluasan dari beberapa penelitian yang ada tentang pengaruh Inflasi, Kurs dan BI 7 Day Rate terhadap saham. Perbedaan penelitian ini dengan penelitian sebelumnya yaitu pada obyek perusahaan yang diteliti yang lebih mengutamakan saham syariah dan tahun periode, peneliti ingin mengetahui apakah hasil penelitian sama apabila diterapkan pada jenis objek yang berbeda. Berdasarkan penelitian terdahulu yang telah diuraikan diatas, penelitian ingin menguji lebih lanjut untuk mengetahui pengaruh Inflasi, Kurs, dan BI 7 Day Rate terhadap indeks saham syariah Indonesia (ISSI) di bursa efek indonesia (BEI) periode 2015-2020. Penelitian kali ini bertujuan untuk mengetahui dan menganalisis pengaruh Infalsi, Kurs dan BI 7 Day Rate terhadap indeks saham syariah Indonesia. Adapun secara spesifik rumusan masalah yang akan diteliti dan dikaji dalam penelitian dirumuskan dalam bentuk pertanyaan dan sebagai berikut: pertama, Bagaimana pengaruh inflasi terhadap Indeks Saham Syariah Indonesia (ISSI) di Bursa Efek Indonesia Periode 2015-2020? Kedua, Bagaimana pengaruh kurs terhadap Indeks Saham Syariah Indonesia (ISSI) di Bursa Efek Indonesia Periode 2015-2020? Ketiga, Bagaimana pengaruh BI 7-Day Rate terhadap Indeks Saham Syariah Indonesia (ISSI) di Bursa Efek Indonesia Periode 2015-2020?

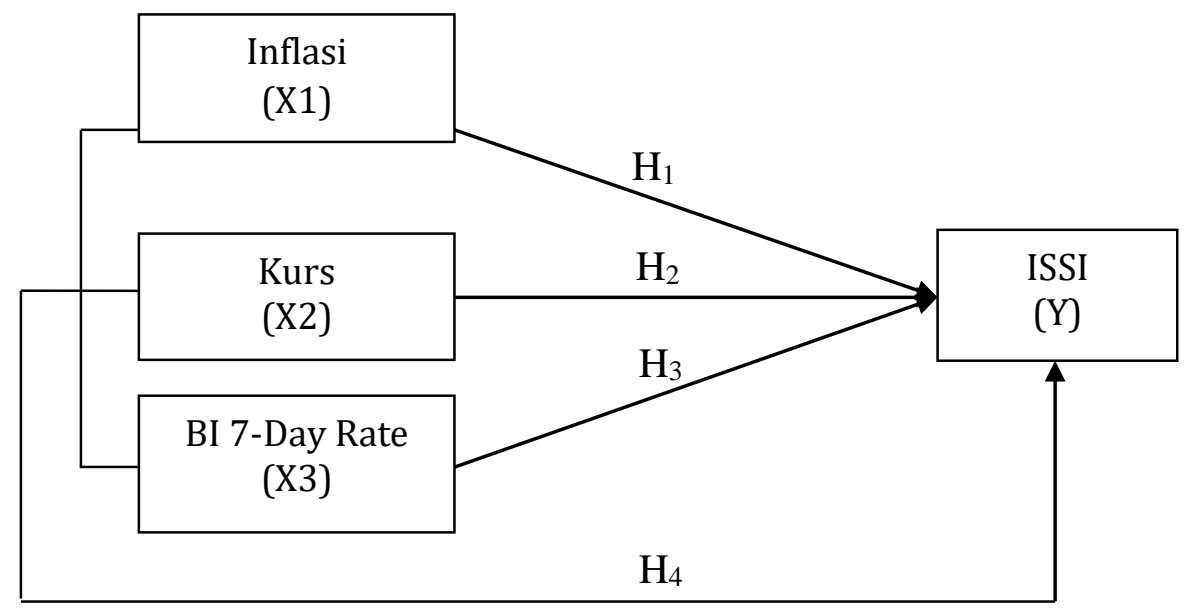

Gambar 1: Model Penelitian 


\subsection{Hipotesis}

a. $\mathrm{H}_{1}$ : Diduga terdapat pengaruh positif signifikan antara inflasi terhadap saham indeks saham syariah Indonesia (ISSI) periode 2015-2020

b. $\mathrm{H}_{2}$ : Diduga terdapat pengaruh negatif signifikan antara kurs terhadap saham indeks saham syariah Indonesia (ISSI) periode 2015-2020

c. $\mathrm{H}_{3}$ : Diduga terdapat pengaruh negatif signifikan antara BI 7-Day Rate terhadap saham indeks saham syariah Indonesia (ISSI) periode 2015-2020

d. $\mathrm{H}_{4}$ : Diduga terdapat pengaruh signifikan antara inflasi, kurs dan BI 7-Day Rate terhadap saham indeks saham syariah Indonesia (ISSI) periode 20152020

\section{TEORI DAN METODE}

\subsubsection{Indeks saham syariah Indonesia (ISSI)}

PT Bursa Efek Indonesia (BEI) mulai tanggal 12 Mei 2011 meluncurkan indeks harga saham baru dengan nama Indeks Saham Syariah Indonesia (ISSI) terhadap berkembangnya minat akan efek syariah tersebut. Perbedaan antara Jakarta Islamic Indeks (JII) tersebut hanya terdiri dari saham syariahnya saja yang tercatat di bursa efek Indonesia (BEI)(Febrian \& Mardian, 2017), sedangkan Indeks Saham Syariah Indonesia (ISSI) merupakan indeks saham yang mencerminkan keseluruhan saham syariah yang tercatat di Bursa Efek Indonesia dan saham-saham tersebut terdaftar dalam Daftar Efek Syariah (DES) Konstituen ISSI direview setiap enam bulan sekali (Mei dan November) dan dipublikasikan pada awal bulan berikutnyayang dikeluarkan oleh BAPEPAM dan LK. Konstituen IIS juga melakukan penyesuaian apabila ada saham syariah yang baru tercatat atau dihapuskan dari Daftar Efek Syariah (DES) www.idx.co.id (Inflasi et al., 2017)(Hana, 2018).

\subsubsection{Indeks Saham}

Samsul (2015) Indeks saham merupakan harga saham yang dinyatakan dalam indeks. Untuk kepentingan return saham yang berkaitan dengan kepentingan analisis, penggunaan indeks saham jauh lebih baik dari pada harga saham dikarenakan agar dapat menghindari baik akibat corporate action. Indeks yang sering terdapat di media-media adalah indeks harga saham gabungan (IHSG) (composite stock price index), yang artinya indeks tersebut mencerminkan pergerakan seluruh saham yang terdapat di bursa (Sa'adah \& Suhadak, 2019).

\subsubsection{Saham}

(Ningsih \& Waspada, 2018) Saham adalah salah satu instumen investasi bagi para investor untuk memperoleh keuntungan. Menurut Irham Fahmi (2012) saham merupakan tanda bukti penyertaan kepemilikan modal dana pada suatu perusahaan, kerta yang tercantum dengan jelas nilai nominal, nama perusahaan, disertai dengan hak dan kewajiban yang dijelaskan kepada setiap pemegangnya dan persedian yang siap untuk dijual. Umum (2013) menyatakan saham merupakan sertifikat yang menunjukan bukti kepemilikan suatu perusahaan dan pemegang saham memiliki hak klaim atas penghasilan dan aktiva perusahaan (Saufi, 2018).

\subsubsection{Pasar Modal}

Sawidji (2015) menyatakan bahwa pasar modal dijadikan tolak ukur kemodernan yang merupakan suatu bangsa berhak menyandang predikat modern kalau pasar modalnya maju (Ni Wayan Sri Asih Masithah Akbar, 2016). Pasar modal adalah sebagai suatu indikator perekonomian terhadap suatu 
negara. Pada dasarnya pasar modal adalah pasar atau sarana transaksi bagi para investor dalam berbagai instrumen keuangan ataupun sebagai surat berharga dimana bisa diperjual belikan dalam bentuk utang ataupun modal dan pasar modal memberikan fasilitas untuk mempertemukan antara kedua belah pihak surplus dana dengan pihak yang membutuhkan dana dalam kerangka investasi (Abdul Jabar \& Cahyadi, 2020).

\subsubsection{Pasar Modal Syariah}

Menurut Sutendi (2011), Pasar modal syariah adalah pasar modal yang dijalankan dengan prinsip-prinsip syariah, disetiap transaksi surat berharga dipasar modal dilaksanakan sesuai dengan ketentuan syariat Islam (Saufi, 2018)(Hidayah, Aslicha, \& Hana, 2020)

\subsubsection{Investasi}

Menurut Eduardus Tandelilin (2001) Investasi adalah komitmen atas sejumlah dana atau sumberdaya lainnya yang dilakukan pada saat ini, dengan tujuan memperoleh sejumlah keuntungan dimasa datang. Istilah investasi bisa berkaitan dengan berbagai macam aktivitas. Menginvestasikan sejumlah dana pada asset riil (tanah, emas, mesin dan bangunan), maupun asset financial (deposito, saham ataupun obligasi) merupakan investasi yang biasa dilakukan (Maslikha, Puspitaningtyas, Prakoso Program Studi Administrasi Bisnis, \& Universitas Jember Jln Kalimantan, 2011).

Pihak-pihak yang melakukan kegiatan investasi disebut investor, investor pada umumnya bisa digolongkan menjadi dua yaitu investor individual dan investor institusional. Investor individual terdiri dari individu-individu yang melakukan aktivitas investasi (Izzati, Safitri, \& Hana, 2020). Sedangkan investor institusional biasanya terdiri dari perusahaan-perusahaan asuransi, lembaga penyimpan dana (bank dan lembaga simpan-pinjam), lembaga dana pensiun, maupun perusahaan investasi (Saufi, 2018)(Riftiani, Lestari, \& Hana, 2020).

\subsubsection{Inflasi}

Menurut Fahmi (2011) inflasi merupakan salah satu kejadian yang menggambarkan situasi dan kondisi dimana harga barang mengalami kenaikan dan nilai mata uang mengalami pelemahan, dan jika terjadi secara terus menerus, maka akan mengakibatkan pada memburuknya kondisi ekonomi secara menyeluruh serta mampu mengguncang tatanan stabilitas politik suatu negara. Menurut Nopirin (2004) inflasi adalah proses kenaikan harga-harga secara umum dan terus menerus.Inflasi merupakan salah satu bentuk penyakit ekonomi yang sering muncul dan dialami oleh hampir semua negara (Harsono \& Wonokinasih, 2018)

Menururt boediono, inflasi merupakan kecenderenguan dari harga untuk menaikan secara umum dan terus menerus. Ada tiga syarat yang dapat dikatakan terjadinya inflasi, yaitu adanya kenaikan harga, kenaikan terjadi terhadap harga barang secara umum dan kenaikan tersebut berlangsung cukup lama (Hidayati, 2014)

\subsubsection{Kurs}

Kurs atau yang sering dikenal dengan Nilai Tukar merupakan catatan harga pasar dari mata uang asing dalam harga mata uang domestik, yaitu harga mata uang domestik dalam mata uang asing, nilai tukut uang mempresentasikan tingkat harga pertukaran dari mata uang satu ke mata uang yang lainnya dan digunakan berbagai transaksi. Transaksi yang digunakan yaitu transaksi perdagangan internasional (Mufidhoh, Andriyanto, \& Haerudin, 2017) 
Eachern (2000) kurs adalah harga suatu mata uang atas dasar mata uang yang lain. Semakin besar permintaan atas suatu mata uang atau semakin kecil penawarannya, maka semakin tinggi pula kursnya. Kurs mempengaruhi harga barang impor, sehingga mempengaruhi arus perdagangan luar negeri (Murni et al., 2018)

Menurut Karim (2008) Kurs mata uang adalah catatan harga pasar dari mata ang asing dalam harga mata uang domestik, yaitu harga mata uang domestic dalam mata uang asing. Investor asing yang melakukan disversifikasi portofolio akan mengharapkan return atas investasinya dalam dua hal yaitu saham dan valas. Mereka juga menanggung risiko atas saham dan risiko nilai tukar. Menurut Rachmawati (2015) laba yang diperoleh dari kepemilikan saham akan dikonversikan pada mata uang negara mereka, jika kurs mata uang negara asal investor tersebut menguat maka keuntungan yang didapat akan lebih kecil dibanding keuntungan yang di dapat oleh investor domestik negara tempat ia menginvestasikan modal dan berlaku (Saufi, 2018).

\subsubsection{BI 7-Day Rate}

BI 7 day repo rate merupakan suku bunga acuan yang baru, dimana suku bunga tersebut mempunyai hubungan yang lebih kuat terhadap suku bunga pasar uang yang sifatnya transaksional atau diperdagangkan di pasar dan mendorong pendalaman pasar keuangan (Ichwani \& Dewi, 2018). BI mereformulasikan Suku Bunga Kebijakan dari BI Rate menjadi BI 7-Day (Reverse) Repo Rate, hal tersebut dilakukan agar meningkatkan efektifitas transmisi kebijakan moneter, perubahan kebijakan Suku Bunga tersebut berlaku efektif sejak 19 Agustus 2016. Dalam masa transisi sampai dengan sebelum 19 Agustus 2016, BI akan menggunakan BI Rate sebagai suku bunga kebijakan. Dalam periode yang sama BI akan mengumumkan BI 7-Day (Reverse) Repo Rate sebagai bagian dari suku bungan operasi moneter (term structure) (Ekonomi et al., 2017)

\subsection{Metode Penelitian}

\subsubsection{Pendekatan penelitian}

Penelitian ini merupakan penelitian kuantitatif. Wiyono (2011) pada penelitian kuantitatif maka yang diteliti terkait dengan penyebaran suatu gejala atau frekuensi adanya hubungan antara gejala dengan factor lain dalam suatu komunitas tertentu (Mawarni \& Widiasmara, 2018). Penelitian ini meneliti pengaruh inflasi, kurs dan bi 7 day rate yang diprediksi mampu mempengaruhi pergerakan indeks harga saham yang terdapat di indeks saham syariah Indonesia (ISSI) pada periode januari 2015-desember 2020. Data yang di analisis dalam penelitian ini merupakan data sekunder yang bersumber dari website yang berkaitan dengan variable penelitian yaitu indeks sahamsyariah Indonesia (ISSI) melalui www.idx.com, inflasi dan bi 7-day rate dari situs resmi www.bi.go.id, dan data kurs dari www.kemendag.go.id.

\subsubsection{Populasi dan Sampel}

Menurut Sugiyono (2012) Populasi merupakan wilayah generalisasi yang terdiri atas obyek dan subyekyang mempunyai kualitas dan karakteristik tertentu yang ditetapkan oleh penelitian untuk dipelajari dan kemudian ditarik kesimpulannya (saifudin zuhri dkk., 2019). Populasi yang digunakan dalam penelitian ini adalah data indeks saham syariah Indonesia (ISSI), bi 7 day rate, kurs dan inflasi pada tahun 2015-2020.

Menurut sugiyono (2012) teknik sampling adalah teknik pengambilan sampel, sampel yang diambil adalah menggunakan semua jumlah populasi yang ada yaitu 
indeks saham syariah Indonesia (ISSI)(Saufi, 2018). Sehingga yang menjadi sampel dalam penelitian ini merupakan data indeks saham syariah Indonesia (ISSI) dari bulan januari 2015-desember 2020 sejumlah 72 sampel data, tujuan pemilihan data bulanan ini untuk melihat secara lebih detail pengaruh variable inflasi $\left(\mathrm{X}_{1}\right)$, kurs $\left(\mathrm{X}_{2}\right)$ dan bi 7 day rate $\left(\mathrm{X}_{3}\right)$ terhadap variable indeks saham syariah Indonesia (ISSI) (Y).

\subsubsection{Jenis dan sumber data}

Berdasarkan cara perolehannya penelitian ini menggunakan data sekunder yang didapati secara tidak langsung dari objek yang diteliti.

Sugiyono (2017) metode penelitian kuantitatif merupakan metode penelitian yang berlandaskan pada filsafat positivism, yang digunakan untuk meneliti populasi atupun sampel tersebut, pengumpulan data menggunakan instrument penelitian, analisis data bersifat kuantitatif statistic yang bertujuan untuk menguji hipotesis yang telah ditetapkan (Sa'adah \& Suhadak, 2019).

\subsubsection{Teknik pengumpulan data}

Muhammad (2008) Metode pengumpulan data pada penelitian ini menggunakan metode dokumentasi, metode dokumentasi yaitu metode pengumpulkan data berupa data-data tertulis yang mengandung keterangan dan penjelasan serta pemiki ran tentang fenomena yang masih aktual dan sesuai dengan masalah yang diteliti (Husnul, Hidayat, \& Sulasmiyati, 2017). Dalam penelitian ini metode yang digunakan untuk pengumpulan data seperti melalui website dan studi perpustakaan, data yang digunakan dalam pengumpulan ini adalah Inflasi, Kurs, BI 7 Day Rate dan Indeks Saham Syariah Indonesia (ISSI) periode 2015-2020.

\subsubsection{Teknik analisis data}

Metode yang digunakan dalam analisis pada penelitian ini adalah metode analisis Erorr Correction Model (ECM). Analissi ini gunakan untuk mengetahui seberapa besar pengaruh dari beberapa variable independen terhadap variable dependen, sebelum melakukan uji Erorr Correction Model ECM yang digunakan untuk menguji pengaruh antara Inflasi, Kurs dan BI 7-Day Rate terhadap Indeks Sahama Syariah Indonesia (ISSI). Analisis data pada penelitian ini menggunakan bantuan program Eviews 8.

\section{HASIL DAN PEMBAHASAN}

\subsection{Hasil Penelitian}

Berdasarkan Penelitian ini menggunakan data sekunder yang terdiri dari Inflasi, Kurs, BI 7 Day Rate, dan Indeks Saham Syariah Indonesia (ISSI) yang diambil dari publikasi badan pusat statistic (BPS), bank Indonesia (Bank Indonesia) dan Indonesia Stock Exchange (IDX) selama kurun waktu 6 tahun yakni tahun 20152020. Berikut di bawah ini adalah hasil uji statistic menggunakan program eviews 8.

Tabel 3.1. Hasil uji unit dengan Augment Dickey-Fullers test pada level

Null Hypothesis: D(RES) has a unit root

Exogenous: Constant

Lag Length: 0 (Automatic - based on SIC, maxlag=10)

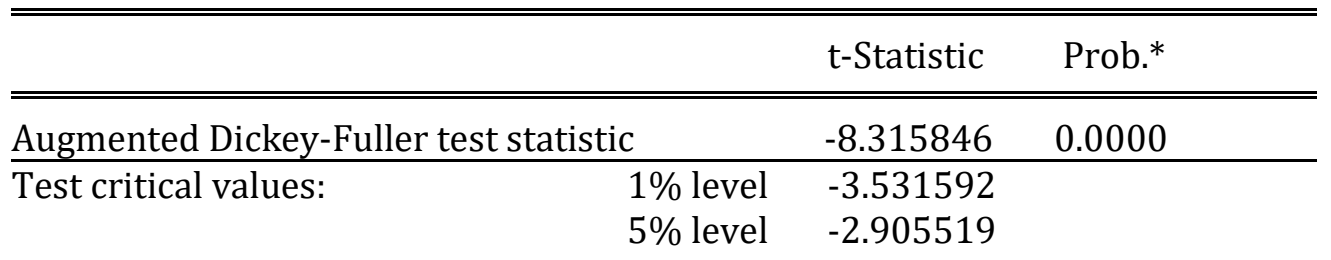


*MacKinnon (1996) one-sided p-values.

Sumber: Data diolah, Eviews 8

Berdasarkan hasil olah data tabel 3.1 diketahui data sudah stasioner pada level 1 karena nilai prob 0.0000 , dengan demikian maka semua variabel stasioner pada level

Analisis time series pada $1^{\text {st }}$ diiference

Hio : $\rho 1 \geq 0,05$ (Data tidak stasioner)

Hi1 : $\rho 1<0,05$ (Data stasioner)

\section{Tabel 3.2 Uji kointegrasi dickey fuller resudual}

Null Hypothesis: D(RESID) has a unit root

Exogenous: Constant

Lag Length: 0 (Automatic - based on SIC, maxlag=10)

\begin{tabular}{llll}
\hline \hline & & t-Statistic & Prob.* \\
\hline \hline Augmented Dickey-Fuller test statistic & -8.983974 & 0.0000 \\
\hline Test critical values: & 1\% level & -3.533204 & \\
& 5\% level & -2.906210 & \\
& $10 \%$ level & -2.590628 & \\
\hline \hline
\end{tabular}

Sumber: Data diolah, Eviews 8, 2020

Berdasarkan pengujian dengan nilai yang dihasilkan, didapatkan residual dari regresi stasioner pada nilai (prob 0.0000), dengan demikian dapat dikatakan data tersebut terkointegrasi.

Uji Asumsi Klasik

a. Uji normalitas

Tabel 3.3 Hasil Uji Normalitas

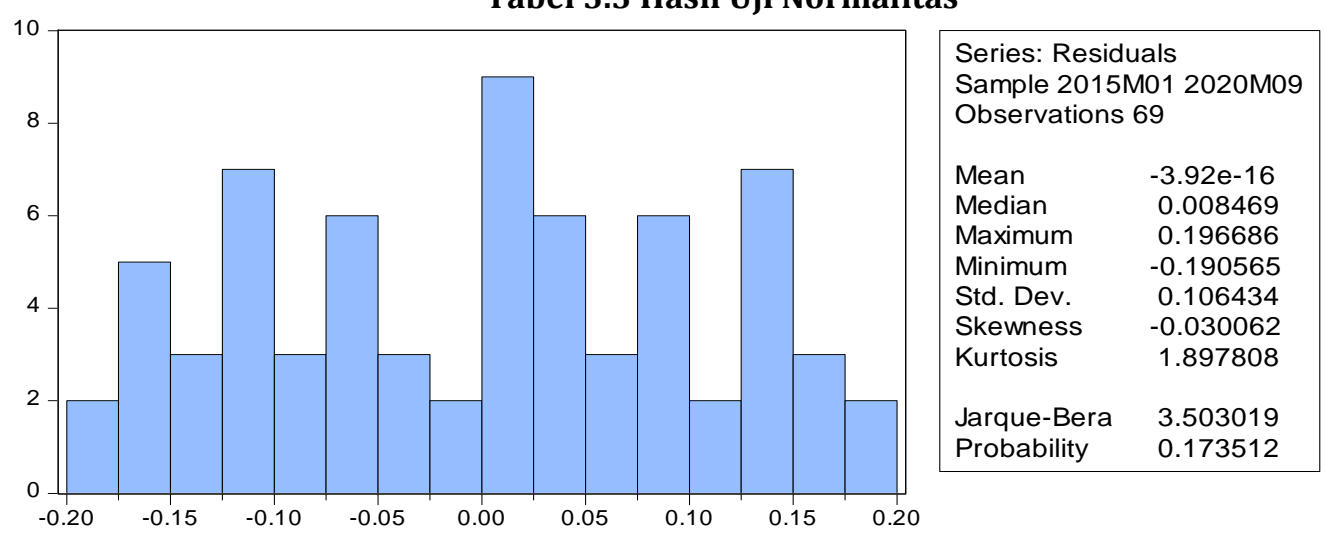

Sumber: Uji Normalitas residual dengan Eviews 8

Berdasarkan hasil uji normalitas residual diperoleh nilai Jarque-Bera sebesar 3.503019 dengan nilai $p$ sebesar 0.173512 , karena nilai $p>0,05$ sehingga residuals dikatakan berdistribusi normal.

b. Uji Heteroskedastisitas

Tabel 3.4 Hasil Uji Heteroskedasitas 
Heteroskedasticity Test: White

\begin{tabular}{llll}
\hline \hline F-statistic & 9.709867 & Prob. F(8,60) & 0.0000 \\
Obs*R-squared & 38.93004 & Prob. Chi-Square(2) & 0.0000 \\
Scaled explained SS & 15.50840 & Prob. Chi-Square(2) & 0.0500 \\
\hline \hline
\end{tabular}

Sumber: Data diolah, Eviews 10

Berdasarkan hasil uji Heteroskedastisitas diperoleh nilai Obs*R-Squared sebesar 38.93004 dengan nilai $\mathrm{p}$ sebesar 0.0000 , karena nilai $\mathrm{p}<0,05$ sehingga model regresi bersifat homodaskedastisitas dengan kata lain tidak ada masalah heteroskedastisitas.

c. Uji Autokorelasi

Tabel 3.5 Hasil uji Autokorelasi

Breusch-Godfrey Serial Correlation LM Test:

\begin{tabular}{llll}
\hline \hline F-statistic & 208.9737 & Prob. F(2,63) & 0.0000 \\
Obs*R-squared & 59.96159 & Prob. Chi-Square(2) & 0.0000 \\
\hline \hline
\end{tabular}

Sumber: Data diolah, Eviews 8.

Berdasarkan hasil uji Autokorelasi diperoleh nilai Obs*R-Squared sebesar 59.96159 dengan nilai $p$ sebesar 0.0000 , karena nilai $p<0,05$ sehingga model regresi tersebut tidak ada masalah autokorelasi.

d. Uji Multikolinearitas

Tabel 3.6 Hasil Uji Multikolinearitas

\begin{tabular}{|l|r|r|r|r|}
\hline & \multicolumn{1}{|c|}{ LNISSI } & \multicolumn{1}{c|}{ LNKURS } & \multicolumn{1}{c|}{ INFLASI } & \multicolumn{1}{c|}{ BIRATE } \\
\hline LNISSI & 1 & 0.036506 & -0.426158 & -0.490638 \\
\hline LNKURS & 0.036506 & 1 & -0.501919 & -0.292974 \\
\hline INFLASI & -0.426158 & -0.501919 & 1 & 0.720319 \\
\hline BIRATE & -0.490638 & -0.292974 & 0.720319 & 1 \\
\hline
\end{tabular}

Sumber: Data Diolah, Eviews 8

Berdasarkan hasil uji multikolinearitas menunjukkan tidak terdapat nilai korelasi yang tinggi antar variabel, sehingga disimpulkan tidak terdapat multikolinearitas antar variabel bebas.

\section{Hasil Uji Hipotesis}

a. Etimasi persamaan jangka panjang

Dependent Variable: LNISSI

Method: Least Squares

Date: 12/08/20 Time: 07:38

Sample (adjusted): 2015M02 2020M09

Included observations: 68 after adjustments

Tabel 3.7 Hasil Estimasi Jangka Panjang

\begin{tabular}{cllll}
\hline \hline Variable & Coefficient & Std. Error & t-Statistic & Prob. \\
\hline \hline C & 30.61191 & 5.030791 & 6.084909 & 0.0000 \\
LNKURS & -0.596248 & 0.288173 & -2.069061 & 0.0426
\end{tabular}




\begin{tabular}{lllll}
\multicolumn{1}{r}{ INFLASI } & -4.213629 & 1.608724 & -2.619236 & 0.0110 \\
\multicolumn{1}{c}{ BIRATE } & -2.451417 & 1.678960 & -1.460081 & 0.1492 \\
\multicolumn{1}{c}{ RESID-1 } & 9.645019 & 3.790782 & 2.544335 & 0.0134 \\
\hline \hline R-squared & 0.347925 & Mean dependent var & 14.99412 \\
Adjusted R-squared & 0.306523 & S.D. dependent var & 0.126364 \\
S.E. of regression & 0.105230 & Akaike info criterion & -1.594652 \\
Sum squared resid & 0.697621 & Schwarz criterion & -1.431453 \\
Log likelihood & 59.21816 & Hannan-Quinn criter. & -1.529987 \\
F-statistic & 8.403662 & Durbin-Watson stat & 0.276871 \\
Prob(F-statistic) & 0.000017 & & \\
\hline \hline
\end{tabular}

Sumber: Data Diolah, Eviews 8

Berdasarkan tabel 3.7 maka diperoleh model ECM jangka panjang sebagai berikut: PEt $=\alpha 0+\alpha 1 \mathrm{INFt}+\alpha 2 \mathrm{LNKURS}+\alpha 3 \mathrm{BI} 7-\mathrm{DAY}+\alpha 4 \mathrm{C}=30.61191-$ 4.213629 INF - 0.596248 LNKURS - 2.451417 BI 7-DAY

Pengaruh Model persamaan jangka panjang tabel 3.7 Memiliki probabilitas Fstatistik sebesar 0.000017 yang berarti signifikan pada $\alpha=0,05$. Hal ini menggambarkan bahwa variabel ISSI pada masing-masing model secara simultan dalam jangka panjang berpengaruh atau mampu menjelaskan variabel tergantungnya yaitu variabel Y.

b. Etimasi persamaan jangka pendek

Dependent Variable: D(LNISSI)

Method: Least Squares

Date: 12/04/20 Time: 15:01

Sample (adjusted): 2015M02 2020M09

Included observations: 68 after adjustments

Tabel 3.8 Hasil Etimasi Jangka Pendek

\begin{tabular}{lllll}
\hline \hline Variable & Coefficient & Std. Error & t-Statistic & Prob. \\
\hline \hline C & 0.002670 & 0.004947 & 0.539727 & 0.5913 \\
D(LNKURS) & -0.631066 & 0.152776 & -4.130661 & 0.0001 \\
D(BIRATE) & 0.317324 & 2.267295 & 0.139957 & 0.8891 \\
D(INFLASI) & -0.291823 & 1.241387 & -0.235078 & 0.8149 \\
RES(-1) & -0.093423 & 0.045314 & -2.061682 & 0.0434 \\
\hline \hline R-squared & 0.252706 & Mean dependent var & 0.000000 \\
Adjusted R-squared & 0.205259 & S.D. dependent var & 0.042986 \\
S.E. of regression & 0.038321 & Akaike info criterion & -3.614956 \\
Sum squared resid & 0.092515 & Schwarz criterion & -3.451757 \\
Log likelihood & 127.9085 & Hannan-Quinn criter. & -3.550292 \\
F-statistic & 5.326042 & Durbin-Watson stat & 1.979561 \\
Prob(F-statistic) & 0.000927 & & \\
\hline \hline
\end{tabular}

Sumber : Data Diolah, Eviews 8 
Berdasarkan tabel 3.8 maka diperoleh model ECM jangka pendek sebagai berikut:

DPEt $=\alpha 1 \mathrm{c}+\alpha 2$ INFLASI $+\alpha 3$ LNKURS $+\alpha 4$ BI 7-DAY,$=0.002670-0.291823$ DINF - 0.631066 LNKURS + 0.317324 BI 7-DAY

Pengaruh Model persamaan jangka panjang tabel 3.8 Memiliki probabilitas Fstatistik sebesar 0.000927 yang berarti signifikan pada tingkat $\alpha=0,05$. Hal ini menggambarkan bahwa variabel bebas pada masing-masing model secara simultan dalam jangka panjang pendek berpengaruh atau mampu menjelaskan variabel tergantungnya yaitu variabel $Y$.

\section{Regresi Linear Berganda}

Dependent Variable: LNISSI

Tabel 3.9 Hasil Regresi Linear Berganda

Method: Least Squares

Date: 12/05/20 Time: 11:31

Sample (adjusted): 2015M01 2020M09

Included observations: 69 after adjustments

\begin{tabular}{lclll}
\hline \hline Variable & Coefficient & Std. Error & t-Statistic & Prob. \\
\hline \hline LNKURS & -0.488826 & 0.291789 & -1.675276 & 0.0987 \\
INFLASI & -2.456836 & 1.505486 & -1.631922 & 0.1075 \\
BIRATE & -3.791182 & 1.639352 & -2.312610 & 0.0239 \\
C & 19.95302 & 2.796178 & 7.135820 & 0.0000 \\
\hline \hline R-squared & 0.282695 & Mean dependent var & 14.99319 \\
Adjusted R- & & & \\
squared & 0.249589 & S.D. dependent var & 0.125669 \\
S.E. of regression & 0.108862 & Akaike info criterion & -1.541246 \\
Sum squared resid & 0.770313 & Schwarz criterion & -1.411733 \\
Log likelihood & 57.17300 & Hannan-Quinn criter. & -1.489864 \\
F-statistic & 8.538998 & Durbin-Watson stat & 0.136865 \\
Prob(F-statistic) & 0.000073 & & \\
\hline \hline
\end{tabular}

Sumber: Data Diolah, Eviews 8

Berdasarkan hasil uji data regresi linear berganda diperoleh nilai R-squared sebesar 0,282695 yang artinya kontribusi variabel independen (X) dalam mempengaruhi variabel dependen (Y) sebesar 28,3\% sementara 71,7\% dijelaskan oleh variabel lain yang tidak diteliti.

\section{Uji Parsial (Uji t)}

Berdasarkan hasil uji t dapat disimpulkan bahwa :

1. Pengaruh kurs terhadap indek saham syariah Indonesia

Dari hasil pengujian regresi diatas dapat diperoleh nilai t sebesar -1.675276 dengan nilai $p$ sebesar 0.0987 , karena nilai $p>0,05$ berarti kurs tidak memiliki pengaruh yang signifikan terhadap indeks saham syariah Indonesia dengan arah negatif.

2. Pengaruh inflasi terhadap indeks saham syariah Indonesia

Dari hasil pengujian regresi diatas dapat diperoleh nilai t sebesar -1.631922 dengan nilai $p$ sebesar 0.1075 , karena nilai $p>0,05$ berarti inflasi tidak memiliki pengaruh yang signifikan terhadap indeks saham syariah Indonesia dengan arah negatif. 
3. Pengaruh bi rate terhadap indeks saham syariah Indonesia

Dari hasil pengujian regresi diatas dapat diperoleh nilai t sebesar -2.312610 dengan nilai p sebesar 0.0239, karena nilai p<0,05 berarti BI 7 Day Rate memiliki pengaruh yang signifikan terhadap indeks saham syariah Indonesia dengan arah negatif.

\section{Uji F (Uji simultan)}

Berdasarkan hasil uji F diperoleh nilai F sebesar 8.538998 dengan nilai p sebesar 0.000073 , karena nilai $p<0,05$ berarti secara bersama-sama (simultan) variabel independen memiliki pengaruh yang signifikan terhadap indeks saham syariah Indonesia.

\subsection{Pembahasan}

a. Pengaruh inflasi terhadap indeks saham syariah Indonesia Hasil uji diatas mengindikasikan variabel inflasi tidak berpengaruh terhadap indeks saham syariah Indonesia $(p>0,05)$, artinya naiknya atau turunnya inflasi tidak akan menurunkan atau menaikkan indeks saham. Hasil tersebut diatas mengindikasikan bahwa tingkat inflasi tidak bisa dijadikan tolak ukur dalam menilai suatu harga saham syariah. Inflasi dalam beberapa definisi merupakan suatu kenaikan harga yang terus menerus dari barang-barang dan jasa secara umum. Inflasi erat kaitannya dengan penurunan kemampuan daya beli baik dalam lingkup individu maupun perusahaan. Gangguan utama terhadap inflasi adalah adanya perubahan pada keseluruhan akan permintaan terhadap barang dan jasa. Dalam dunia investasi Inflasi sangat berpengaruh terlihat dari setiap terjadinya kenaikkan atau penurunan angka inflasi akan mempengaruhi otoritas moneter dalam membuat kebijakan yang pada akhirnya akan mempengaruhi investor dalam penempatan dana investasinya. Hasil penelitian ini sejalan dengan penelitian yang dilakukan oleh Qomariyah (2018), Saputra (2017) serta Widyasa dan Wirokinasih (2018) dimana tingkat inflasi tidak memberikan pengaruh yang signifikan terhadap pergerakan saham di ISSI. Selain menjadi salah saru penyebab pergerakan harga saham, inflasi juga menjadi resiko terhadap daya beli investor akan saham sebuah perusahaan. Apabila inflasi meningkat, investor akan menuntut tambahan premium inflasi untuk meningkatkan kompensasi yang diakibatkan adanya penurunan daya beli (Tandelilin, 2010).

b. Pengaruh kurs terhadap indeks saham syariah Indonesia

Kurs tidak berpengaruh terhadap indeks saham syariah Indonesia ( $p>0,05)$, hal ini berbanding terbalik dengan penelitian yang menemukan bahwa ada pengaruh variabel kurs terhadap indeks saham syariah Indonesia. Pengaruh tersebut dijelaskan nilai tukar mata uang mampu memprestasikan tingkat harga pertukaran dari satu mata uang ke mata uang Negara lainnya dalam berbagai transaksi, termasuk investasi sehingga mampu memberikan terhadap pergerakan harga saham syariah. Hasil penelitian ini sejalan dengan penelitian yang dilakukan oleh Sari (2016) dan Qomariyah (2018) yang mengatakan bahwa Kurs tidak berpengaruh terhadap ISSI. Hasil ini juga sejalan dengan teori Tandelelin (2010) yang mengungkapkan bahwa nilai tukar memiliki kaitan dengan fluktuasi nilai tukar mata uang domestik dengan nilai mata uang negara lain.

c. Pengaruh bi 7-day rate terhadap indeks saham syariah indonesia 
Berdasarkan hasil penelitian diperoleh bahwa variabel makroekonomi bi 7-day rate berpengaruh negatif terhadap indeks saham syariah Indonesia $(p<0,05)$. Hal tersebut berarti BI 7 Day Rate dapat mempengaruhi secara kuat perubahan dari pergerakan harga saham syariah Indonesia. BI Rate merupakan suku bunga kebijakan yang mencerminkan sikap kebijakan moneter yang ditetapkan oleh Bank Indonesia dan diumumkan kepada publik. Bank Indonesia umumnya akan menaikkan BI Rate apabila inflasi ke depan diperkirakan melampaui sasaran yang telah ditetapkan, sebaliknya Bank Indonesia akan menurunkan BI Rate apabila inflasi ke depan diperkirakan berada dibawah sasaran yang telah ditetapkan. Berdasarkan Teori saham dipengaruhi oleh aktivitas makro ekonomi suatu negara. BI Rate yang merupakan bagian dari Instrumen moneter Bank Indonesia selaku Bank Sentral dalam mengendalikan laju tingkat inflasi di Indonesia. Kenaikan tingkat suku bunga dapat menarik perhatian investor untuk menyimpan uangnya dibank, tingkat suku bunga yang terlampau tinggi akan mempengaruhi aliran kas perusahaan sehingga kesempatan-kesempatan untuk berinvestasi yang tidak akan menarik lagi. Artinya naiknya tingkat BI Rate akan berdampak negatif terhadap Indeks Saham Syariah Indonesia (ISSI). Hasil penelitian ini sejalan dengan penelitian yang dilakukan oleh Aulia dan Latief (2020) yang menunjukkan bahwa BI Rate perpengaruh negatif signifikan terhadap Indeks Saham Syariah Indonesia (ISSI).

\section{PENUTUP}

Berdasarkan hasil penelitian yang telah dilakukan maka pada penelitian dapat ditarik kesimpulan sebagai berikut: Inflasi tidak memiliki pengaruh yang signifikan terhadap Indeks Saham Syariah Indonesia. Kurs tidak memiliki pengaruh yang signifikan terhadap Indeks Saham Syariah Indonesia. BI 7 Day Rete memiliki pengaruh yang signifikan terhadap Indeks Saham Syariah Indonesia. 


\section{DAFTAR PUSTAKA}

Abdul Jabar, A. K., \& Cahyadi, I. F. (2020). Pengaruh Exchange Rate, Inflasi, Risiko Sistematis Dan BI Rate Terhadap Return Saham Syariah Di Jakarta Islamic Index (JII) Periode 2015-2018. MALIA: Journal of Islamic Banking and Finance, 4(1), 12. https://doi.org/10.21043/malia.v4i1.8409

Aisiyah, S. S., \& Khoiroh, R. (2015). Analisis Dampak Variabel Makro Ekonomi Terhadap Indeks Saham Syariah Indonesia (ISSI). Jurnal UNISSULA, 2(1), 398412. Retrieved from http://lppmunissula.com/jurnal.unissula.ac.id/index.php/cbam/article/viewFile/323/270

Ekonomi, J., Andalas, D., Tahun, D. I. I., Ilmu, F., Upi, K., \& Padang, Y. (2017). Jurnal ekonomi \& bisnis dharma andalas. Ekonomi Dan Bisnis, 19(1), 113-126.

Febrian, R., \& Mardian, S. (2017). Penerapan PSAK NO. 102 Atas Transaksi Murabahah: Studi Pada Baitul Maal Wa Tamwil Di Depok, Jawa Barat. Ikonomika, 2(1), 213-238. https://doi.org/10.24042/febi.v2i1.943

Hana, K. F. (2018). Dialektika Hukum Trading Saham Syariah di Bursa Efek Indonesia. Tawazun: Journal of Sharia Economic Law, 1(2), 148-160. Retrieved from http://journal.stainkudus.ac.id/index.php/tawazun/index

Harsono, A. R., \& Wonokinasih, S. (2018). Pengaruh Inflasi, Suku Bunga, Dan Nilai Tukar Rupiah Terhadap INdeks Harga Saham Gabungan (Studi pada Bursa Efek Indonesia Periode 2009-2013 ). Jurnal Administrasi Bisnis, 60(2), 102-110.

Hidayah, N. L., Aslicha, G., \& Hana, K. F. (2020). Persepsi Masyarakat tentang Haramnya Investasi di Pasar Modal Syariah. Tawazun: Journal of Sharia Economic Law, 3(1), 31-44. https://doi.org/10.21043/tawazun.v3i1.7530

Hidayati, A. N. (2014). Pengaruh Inflasi, Bi Rate Dan Kurs Terhadap Profitabilitas Bank Syariah Di Indonesia. An-Nisbah: Jurnal Ekonomi Syariah, 1(1). https://doi.org/10.21274/an.2014.1.1.72-97

Husnul, H. M., Hidayat, R. R., \& Sulasmiyati, S. (2017). Analisis pengaruh inflasi, kurs (IDR/USD), Produk Domestik Bruto dan harga emas dunia terhadap Indeks Harga Saham Gabungan. Jurnal Administrasi Bisnis, 53(1), 66-74.

Ichwani, T., \& Dewi, R. S. (2018). Pengaruh Perubahan Bi Rate Menjadi Bi 7 Day. (September 2018), 259-270.

Indeks, T., Syariah, S., \& Issi, I. (2020). “ PENGARUH INFLASI DAN NILAI TUKAR RUPIAH PASCASARJANA INSTITUT AGAMA ISLAM NEGRI ( IAIN ) METRO “ PENGARUH INFLASI DAN NILAI TUKAR RUPIAH TERHADAP INDEKS SAHAM SYARIAH INDONESIA ( ISSI) INSTITUT AGAMA ISLAM NEGRI ( IAIN) METRO.

Inflasi, P., Goverment, I., Sun, B., Munib, M. F., Shanghai, D. A. N., Exchange, S., ... Rate, P. Van. (2019). Pengaruh Inflasi Dan Nilai Tukar Rupiah Terhadap Harga Saham Di Sektor Industri Barang Konsumsi Pada Indeks Saham Syariah Indonesia (Issi) Tahun 2012-2016. E-Jurnal Manajemen Universitas Udayana, 2(4), 255199. https://doi.org/10.24912/jmbk.v2i4.4860

Inflasi, P., Nilai, D. A. N., Rupiah, T., Saham, I., Indonesia, S., \& Tahun, I. (2017). Pengaruh Inflasi Dan Nilai Tukar Rupiah Terhadap Harga Saham Di Sektor Industri Barang Konsumsi Pada Indeks Saham Syariah Indonesia (Issi) Tahun 2012-2016. I-Finance: A Research Journal on Islamic Finance, 3(1), 31-52.

Izzati, I. N., Safitri, D. N., \& Hana, K. F. (2020). Minat investor muda dalam berinvestasi reksa dana di bukalapak. POINT: Jurnal Ekonomi Dan Manajemen, 2(1), 1-8.

Maslikha, H., Puspitaningtyas, Z., Prakoso Program Studi Administrasi Bisnis, A., \& Universitas Jember Jln Kalimantan, F. (2011). Pengaruh Inflasi dan BI Rate 
terhadap IHSG Tahun. Vol. IV Edisi, 1, 62-67.

Mawarni, C. P., \& Widiasmara, A. (2018). Pengaruh FED Rate, Harga Minyak Dunia, BI Rate, Inflasi Dan Kurs Rupiah Terhadap Indeks Saham Syariah Indonesia (ISSI) Periode Tahun 2011-2017. Pengaruh FED Rate, Harga Minyak Dunia, BI Rate, Inflasi Dan Kurs Rupiah Terhadap Indeks Saham Syariah Indonesia (ISSI) Periode Tahun 2011-2017, 2(2), 281-297.

Mufidhoh, U., Andriyanto, I., \& Haerudin. (2017). Analisis Pengaruh Inflasi, Suku Bunga, dan Nilai Tukar Terhadap Kinerja Bank Syariah BUMN (Periode 20142017). Malia, 1(1), 71-90.

Murni, R. C. K. S., Rate, P. V, Kapoh, R. C., Rate, P. Van, Bisnis, E. D., Manajemen, J., ... Rate, P. V. (2018). Analisis Faktor Makroekonomi Terhadap Harga Saham Pada Bank Bumn Devisa Yang Terdaftar Di Bursa Efek Indonesia Periode 2010 - 2018 Analysis of Macroeconomic Factors on Stock Prices on Bumn Devisa Banks Registered in Indonesia Stock Exchange Period 2010-20. 7(4), 4927-4934.

Ni Wayan Sri Asih Masithah Akbar. (2016). Analisis Pengaruh Inflasi, Suku Bunga, Nilai Tukar (Kurs) Dan Pertumbuhan Produk Domestik Bruto (Pdb) Terhadap Indeks Harga Saham Gabungan (Ihsg) Studi Kasus Pada Perusahaan Properti Yang Terdaftar Di Bursa Efek Indonesia.Jurnal Manajemen Dan Akuntansi, 17(1), 43-52.

Ningsih, M. M., \& Waspada, I. (2018). PENGARUH BI RATE DAN INFLASI TERHADAP INDEKS HARGA SAHAM GABUNGAN (Studi Pada Indeks Properti, Real Estate, Dan Building Construction, di BEI Periode 2013 - 2017). Jurnal MANAJERIAL, 3(2), 247-258. https://doi.org/10.17509/manajerial.v17i2.11664

Nurafiati, N. (2019). Perkembangan Pasar Modal Syariah Dan Kontribusinya Terhadap Pertumbuhan Ekonomi Di Indonesia. Inklusif Uurnal Pengkajian Penelitian Ekonomi Dan Hukum Islam), 4(1), 65. https://doi.org/10.24235/inklusif.v4i1.4167

Produk, P., Bruto, D., Terhadap, P. D. B., Yang, P., Di, T., \& Efek, B. (2016). April 2016, volume 17 nomor 1.17(April), 43-52.

Riftiani, R. I., Lestari, D. P., \& Hana, K. F. (2020). Implementation of Sharia Management in Islamic Mutual Fund Products Rizki Ikha Riftiani. Journal of Finance and Islamic Banking, 3(1), 77-94. https://doi.org/10.22515/jfib.v3i1.2626

S, R. A., \& Ekonomi, F. (1945). Prodi Manajemen Surabaya. 41-55.

Sa'adah, U., \& Suhadak. (2019). PENGARUH MAKROEKONOMI TERHADAP KINERJA INDEKS HARGA SAHAM GABUNGAN (IHSG) DAN GOVERNMENT BONDS (Studi pada Negara Indonesia Tahun 2015-2017). 73(1), 151-159.

saifudin zuhri dkk. (2019). Pengaruh Inflasi, kurs, dan BI Rate terhadap Indeks Harga Saham Gabungan Bursa Efek Indonesia (BEI) Periode 2014 - 2018. 41-55.

Saufi, M. (2018). Дифференциально экспрессирующиеся гены нейромедиаторных систем в дорсальном стриатуме самцов мышей с двигательными нарушениямиNo Title. Высшей Нервной Деятельности, 2, 227-249.

Sbi, B., Indeks, T., Saham, H., \& Ihsg, G. (2018). Prosiding 2nd Business and Economics Conference In Utilizing of Modern Techonolgy ISSN 2662-9404.

Selpiana, K. R., \& Badjra, I. B. (2018). Pengaruh Kebijakan Dividen, Nilai Tukar, Leverage, dan Firm Size terhadap Volatilitas Harga Saham. E-Jurnal Manajemen Universitas Udayana, 7(3), https://doi.org/10.24843/ejmunud.2018.v7.i03.p20 
Ulinnuha, M., Susilowati, D. E., \& Hana, K. F. (2020). Persepsi Investor Pemula Terhadap Pembelian Saham Syariah di Indonesia. Jurnal Ilmu Ekonomi Dan Bisnis Islam, 2(1), 1-14. https://doi.org/10.24239/jiebi.v2i1.20.1-14 
Halaman ini sengaja kita kosongkan 